surgeon in one of his most difficult and successful operations with hands, instruments and affected tissues photographed in motion.

We have a daguerreotype portrait of the first short horn bull brought upon Iowa soil. He was imported by Timothy Day from the herd of Brutus J. Clay, of Lexington, Kentucky, in 1852, and was the object of enormous interest at the earliest Iowa agricultural fairs. And we have a negative picturing in motion. Gov. George W. Clarke conferring in 1913 the first medals upon the successful competitors among lowa prize babies.

These instances suggest the precedents and the probability of historical value peculiar to present day motion picture neg. atives.

\title{
CO-OPERATION IN ACQUIRING HISTORIC GROUNDS AND MARKING HISTORIC SITES.
}

The State of Iowa has certain assets not of pecuniary nature that have remained undeveloped or are going to waste. Some of these seem fairly within the scope of the responsibility of the Historical Department of Iowa yet not under the special attention of any other person or public interest. Under the heading of "Notes" in this issue are two such groups of assets respectively entitled "Acquiring Titles to Historic Areas" and "Marking Historic Sites".

While there is something of a feeling that a state should bear all the responsibility for preserving and utilizing these opportunities, such feeling is not universal nor sound. For these are not solely and often not mainly assets of the state, but are or should be part of the natural interest of the people of the localities, or of individuals attached by kinship or associated by other interest. There is a distinct disadvantage to the present and to posterity in this mutuality of interest. "What is everybody's business is nobody's business." 1 Nearly every one wishes these assets recognized, retrieved and realized upon. The Historical Department was allowed by the Thirty-sixth General Assembly certain sums and by implication certain authority to participate with others in 
efforts at doing things in addition to talking and writing about them. The proportionate interest of persons, the locality and the state may not always be discernible. Indeed the proportion of sentimental interest may not be the same as the pecuniary interest of the respective parties, for that would be assuming that sentiment is defined in money value; that a gravestone, for instance, or even a grave has only a money measure, which is absurd. But it is not absurd for all who are concerned in doing any of these worthy things to plan together. Nor will it be unfair nor unpleasant for the Historical Department to contribute more proportionally toward the realizing on a prospect of interest historically, but remote from centers of settlement, than to such as are within the thickly populated portions of the State.

The legislature received these ideas with favor, and assigned to the use of the Fistorical Department certain small amounts to be used in stimulating co-operative interest. It is not much money, but no more was requested. For the purpose of an effort of the next two years it is adequate.

We would appreciate suggestions as to what areas are thought to have sufficient interest to be reserved and marked; what persons, societies, institutions or public officers would welcome the co-operation of the Fistorical Department in authenticating historic or scenic areas or establishing markers at historic sites.

\section{ORIGIN OF THE TERM "NEWSPAPER."}

In Haydn's Dictionary of Dates it is stated that news is not, as many supposed, derived from the adjective "new." In former times (between the years 1795 and 1830) it was the prevalent practice to put over the periodical repablications of the day, the initial letters of the compass, thus: $\mathrm{E}_{\mathrm{S}}^{\mathrm{N}} \mathrm{W}$, importing that these papers contained intelligence from the four quarters of the globe, and from this practice is derived the term "newspaper."-Keokuk, Rickey \& Allyn's Real Estate Bulletin and Commercial Advertiser, Sept. 2, 1867. 
Copyright of Annals of Iowa is the property of State of Iowa, by \& through the State Historical Society of Iowa and its content may not be copied or emailed to multiple sites or posted to a listserv without the copyright holder's express written permission. However, users may print, download, or email articles for individual use. 